Meta

Journal des traducteurs

Translators' Journal

\title{
Knowledge Structure and Training of Translation Teachers: An Exploratory Study of Doctoral Programmes of Translation Studies in Hong Kong
}

\section{Defeng Li et Chunling Zhang}

Volume 56, numéro 3, septembre 2011

URI : https://id.erudit.org/iderudit/1008340ar

DOI : https://doi.org/10.7202/1008340ar

Aller au sommaire du numéro

\section{Éditeur(s)}

Les Presses de l’Université de Montréal

ISSN

0026-0452 (imprimé)

1492-1421 (numérique)

Découvrir la revue

Citer cet article

Li, D. \& Zhang, C. (2011). Knowledge Structure and Training of Translation Teachers: An Exploratory Study of Doctoral Programmes of Translation Studies in Hong Kong. Meta, 56(3), 693-712. https://doi.org/10.7202/1008340ar
Résumé de l'article

L'expansion rapide des programmes de traduction à tous niveaux et partout dans le monde, ces dernières années, a entraîné une hausse de la demande pour des professeurs de traduction qualifiés. Cependant, en dépit d'une pléthore d'études sur l'enseignement de la traduction générale, la formation de ces derniers n'a pas, à ce jour, suscité beaucoup de recherches - non plus que les programmes de M.Phil./Ph. D. en traductologie dans les établissements d'enseignement supérieur. La présente recherche, qui se veut une première tentative en la matière, aborde la question sous l'angle de la formation des enseignants et examine de manière critique la structure des connaissances des professeurs de traduction. Il s'agit d'une étude de cas qualitative menée de 2004 à 2007 sur les programmes et particulièrement sur les besoins et les expériences d'étudiants chercheurs inscrits dans des programmes de M.Phil. et de $\mathrm{Ph}$. D. en traductologie à Hong Kong. Bien que l'étude soit menée dans ce contexte spécifique, les résultats et les conclusions peuvent s'appliquer à d'autres programmes de formation de professeurs de traduction ailleurs dans le monde. 


\title{
Knowledge Structure and Training of Translation Teachers: An Exploratory Study of Doctoral Programmes of Translation Studies in Hong Kong*:
}

\author{
DEFENG LI \\ University of London, London, United Kingdom \\ defeng@soas.ac.uk \\ CHUNLING ZHANG \\ Imperial College, London, United Kingdom \\ chunling8@gmail.com
}

\section{RÉSUMÉ}

L'expansion rapide des programmes de traduction à tous niveaux et partout dans le monde, ces dernières années, a entraîné une hausse de la demande pour des professeurs de traduction qualifiés. Cependant, en dépit d'une pléthore d'études sur l'enseignement de la traduction générale, la formation de ces derniers n'a pas, à ce jour, suscité beaucoup de recherches - non plus que les programmes de M.Phil./Ph. D. en traductologie dans les établissements d'enseignement supérieur. La présente recherche, qui se veut une première tentative en la matière, aborde la question sous l'angle de la formation des enseignants et examine de manière critique la structure des connaissances des professeurs de traduction. Il s'agit d'une étude de cas qualitative menée de 2004 à 2007 sur les programmes et particulièrement sur les besoins et les expériences d'étudiants chercheurs inscrits dans des programmes de M.Phil. et de Ph. D. en traductologie à Hong Kong. Bien que l'étude soit menée dans ce contexte spécifique, les résultats et les conclusions peuvent s'appliquer à d'autres programmes de formation de professeurs de traduction ailleurs dans le monde.

\section{ABSTRACT}

A rapid expansion of translation programmes at all levels the world over in recent years has heightened the demand for quality translation teachers. However, little research has been carried out to date on translation teacher training - M.Phil./Ph.D. programmes of translation studies in tertiary institutions despite a plethora of studies on general translation teaching. The present study, intended as an initial attempt to address the issue, approaches the topic from a teacher education perspective and looks critically at the knowledge structure of translation teachers. On this basis, the present article reports on a qualitative case study conducted in 2004-2007 on the curriculums and particularly the needs and experiences of the research students at the M.Phil./Ph.D. programmes of translation studies in Hong Kong. Although the study was conducted in the context of Hong Kong, the findings and implications may apply to other translation teacher training programmes the world over.

\section{MOTS-CLÉS/KEYWORDS}

programme de doctorat, formation, professeurs de traduction, structures de connaissances, Hong Kong

doctoral programme, training, translation teachers, knowledge structure, Hong Kong 


\section{Introduction}

The past decade has witnessed a rapid expansion of translation programmes worldwide at both undergraduate and postgraduate levels (e.g., the MTI ${ }^{1}$ and BA translation programmes in P. R. China and MA taught programmes of translation and interpreting in the UK). One study in 2008 estimated that there were over 70 MA translation (studies) programmes in the UK alone (Chan 2008). Meanwhile the number of research degree programmes has also increased considerably in many countries. For instance, in Hong Kong, a region of approximately seven million residents, seven of all the nine government funded tertiary institutions offer BA degrees in translation and six offer M.Phil. and Ph.D. degrees in Translation Studies. Such a fast and vast growth of translation programmes has heightened the demand for qualified translation (studies) teachers, who in most instances are graduates of research degree programmes. Despite the plethora of research on training of professional translators and interpreters, very few studies have been conducted on the training of research students in Translation Studies - future translation/interpreting teachers and researchers. As Gabr (2001) observed,

[u]ntil very recently, the training of translator trainers hardly received any [research] attention. Translator trainers have been self-made practitioners with no formal training based on properly conducted training needs assessment (TNA) or, therefore, clearly defined objectives (Gabr 2001: 1).

Consequently, we have little theoretical understanding of the research degree programmes in Translation Studies in general and many pedagogical questions about them are yet to be answered, for example, what are the objectives of such programmes? What are the admission and graduation requirements of these programmes? To what extent are students' needs met in these programmes? What are their experiences of writing their theses? The present project intends to fill the gap and explore, through a case study of doctoral programmes of Translation Studies in the context of the Chinese Hong Kong, some of the questions.

\section{Training translator trainers}

Training translator trainers or translation teacher education has so far been mostly associated with various crash courses for training people to teach translation. For instance, over the last couple of years, several summer programmes for the training of translator trainers have been run yearly by Université de Rennes 2 (France), Universitat Rovira i Virgili (Spain), and Monterey Institute of International Studies (USA). Those attending such programmes were "teachers/trainers who need to develop their skills or professional translators who are considering teaching translation" (Gabr 2001: 8).

Gabr made a critical review of the above-mentioned three training programmes for translation teachers and found:

[...] these courses, particularly the first two, lack some prerequisites of a sound translator-trainer development programme. This deficiency is evident in several phases, from the admission requirements to the contents covered and the duration of the training sessions. Some of the components of these three seminars do not seem to adequately meet the objective of developing efficient translator trainers. (Gabr 2001: 1) 
Surprisingly, little research attention has been given to translation research degree programmes where translator trainers are trained. ${ }^{2}$ This could be due to the fact that in the past there used to be very few research translation programmes offering M.Phil. ${ }^{3}$ or Ph.D. degrees in Translation Studies. But over the past ten years, the situation has changed considerably. For instance, in Hong Kong, six of the nine tertiary institutions offer doctorate degrees in translation studies. These research programmes are the birthplaces of translation teachers and thus deserve our serious research efforts. It is therefore very encouraging to note that training of research degree students has finally begun to attract the attention of the translation studies community. For instance, as of the time when this article is written, the new journal of Translator and Interpreter Trainer is preparing a special issue on Training for Doctoral Research. Also, in December 2007, a working group was formed in Europe on Integration of Doctoral Programmes in Translation Studies with the ambition to draw a map of doctoral programmes, collect data from them, and set up a forum for the exchange of best practices.

Although in the short term, short crash courses such as summer programmes of teacher training will exist to meet the needs of some teachers, regular doctoral programmes have to operate as the cradle of future scholars and teachers of Translation Studies. Thus the present study is not concerned about short crash courses and/or seminars, but rather focused on translation research degree programmes from a knowledge structure perspective.

\section{Knowledge structure of translation teachers}

Literature in teacher education abounds in explorations and delineation of teacher knowledge structure. A number of models have been proposed to characterize the components making up an effective teacher (see Ball 1988; Carter and Doyle 1987; Connelly and Clandinin 1985; Elbaz 1983; Leinhart and Smith 1985; Shulman 1986a; 1986b; 1987; see Johnson and Irujo 2001 for a review). Of all, Shulman's (1987) formulation of the knowledge base of teaching is perhaps the most influential one, comprising a set of different categories of knowledge:

1) content knowledge;

2) general pedagogical knowledge (pedagogical issues that "transcend subject matter");

3) curriculum knowledge;

4) pedagogical content knowledge (the "special amalgam of content and pedagogy that is uniquely the province of teachers");

5) knowledge of learners and their characteristics;

6) knowledge of educational contexts (at both micro- and macro-levels);

7) knowledge of educational ends, purposes, and values.

(adapted from Shulman 1987: 8)

Further, he found that teachers drew upon their knowledge base for teaching to guide their instructional choices and actions (Shulman 1987). While Shuman's formulation is illuminating, Day and Conklin's (1992) model of second language teacher knowledge is perhaps more relevant for translation teacher education. The latter claims that the knowledge base of a second language teacher consists of the following four types of knowledge: 
1) Content knowledge: knowledge of the subject matter (what ESL/EFL teachers teach);

2) Pedagogic knowledge: knowledge of generic teaching strategies, beliefs and practices, regardless of the focus of the subject matter (how we teach);

3) Pedagogic content knowledge: the specialized knowledge of how to represent content knowledge in diverse ways that students can understand; the knowledge of how students come to understand the subject matter, what difficulties they are likely to encounter when learning it, what misconceptions interfere with learning, and how to overcome these problems (how we teach ESL/EFL in general; or how we teach ESL/EFL reading or writing in particular, for example);

4) Support knowledge: the knowledge of the various disciplines that inform our approach to the teaching and learning of English.

(Day 1993)

In recent years, several translation scholars/teacher trainers have also discussed the components of the knowledge of translation teachers though perhaps not exactly in the same terms as "teacher knowledge base." First, translation teachers should have the translation experience. Gouadec (2000) argues that as a start for a translation teacher, the teacher should spend one month in each of the three following situations:

1) Working in a translation firm (either as a translator, a reviser, or a terminologist);

2) Working in an in-house translation service (same as above);

3) Being a free-lance professional (same as above).

(Gouadec as cited in Pym 2000: 224-225)

Rosas supports Gouadec that translator trainers need to be first of all practicing translators.

Since one of the main tasks of the social constructivist teacher is to represent the community in which the apprentices wish to take part, translator trainers should be active translators or, at least, have ample professional experience in the area. This way, it will also be easier to take real projects to the classroom (with the clients' approval) or help students get such projects, enabling them to do just what professionals do: translate real texts, for real clients and real readers/users. (Rosas 2004)

Besides, translation teachers should obviously know how to teach. Gabr believes that

Teaching is a very difficult task. Imparting knowledge and experience to another person not only requires mastery of the subject matter, but also mastery of the communication of knowledge. Therefore, a T\&I professor has to have knowledge and experience in T\&I and the ability to teach. (Gabr 2001:2)

Gabr holds that

since new roles require new skills, translation teachers need training not only in translation pedagogy, translation theory, subject matter expertise, and necessary professional knowledge, but in quality concepts, tools, methods, and skills as well (Gabr 2004: 1).

Translation training is now mostly conducted at post-secondary level, where teachers are required to carry out research and contribute to research of the area of their interests. Thus translation teachers still need a third knowledge, i.e., the knowledge to carry out academic research. This is perhaps one of the most striking differences between K-12 teachers and post-secondary teachers. Some might argue that teachers of elementary or secondary schools are also expected to carry out research. 
However, in most cases, the primary goal of their research is to assist their teaching alone.

In a nutshell, we can say that a translation teacher is a combination of a teacher and a researcher as well as a practicing translator. Based on this understanding and mostly using Day's model, I came up with a knowledge structure of translation teachers as comprising knowledge of teaching, research and the trade. I first presented the following model at a translation education conference several years ago:

1) Knowledge of Teaching

- Content knowledge: knowledge of the subject matter (what translation teachers teach); e.g., translation theory, language studies for translators, culture and translation;

- Pedagogic knowledge: knowledge of generic teaching strategies, beliefs and practices, regardless of the focus of the subject matter (how we teach); e.g., classroom management, motivation, decision making;

- Pedagogic content knowledge: the specialized knowledge of how to represent content knowledge in diverse ways that students can understand; the knowledge of how students come to understand the subject matter, what difficulties they are likely to encounter when learning it, what misconceptions interfere with learning, and how to overcome these problems (how we teach translation in general; or how we teach legal translation or localization in particular, for example); e.g., teaching translation skills, translation materials development, translation assessment and evaluation, translation programme and curriculum evaluation and development, translation teaching methods;

- Support knowledge: the knowledge of the various disciplines that inform our approach to the teaching and learning of translation; e.g., education, psychology, psycholinguistics, linguistics, second language acquisition, sociolinguistics.

2) Knowledge of Research: the knowledge to carry out research on Translation Studies and translation practice, e.g., research methods.

3) Knowledge of the Trade: translating abilities and the knowledge of the profession (e.g., the market; the technology).

This model of knowledge structure can also be represented in the following figure.

FIGURE 1

Knowledge Structure of Translation Teachers

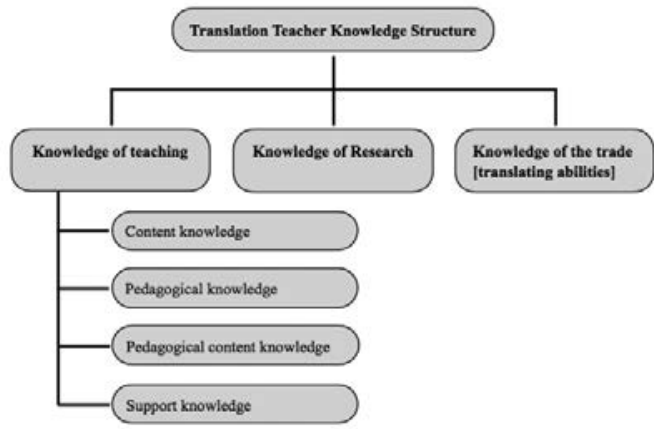


The present exploration of translation research degree programmes in Hong Kong was undertaken against mainly such a model of translation teacher knowledge. The following questions were used to guide the project but the exploration was by no means limited to them:

a) What translation research programmes in Hong Kong tertiary institutions are like (their admission requirements, programme objectives and aims, courses for research students, graduation requirements, etc.)?

b) What are the needs of the translation research students?

c) To what extent their needs have been met?

\section{Design of the study}

This project was designed as a qualitative case study, in which interviews were supplemented with a questionnaire survey of students' background information and their general perceptions and understanding of some focal issues in training translation teachers and researchers. Altogether nine current Ph.D. students studying Translation Studies at Hong Kong universities and two recent doctoral graduates were interviewed (see Table 1 below). The questions were centered on the participants' experiences of studying at these Ph.D. programmes, their needs and expectations, and their perceptions of the programmes. All the conversations were recorded and later on transcribed for analysis. Besides the interviews, curricular documents of different research programs at Hong Kong tertiary institutions were also collected for analysis. These included materials in the form of postgraduate handbooks, study schemes, programme leaflets, curricular booklets and the like.

TABLE 1

Interview participants

\begin{tabular}{|l|l|l|l|l|l|l|l|l|}
\hline Names & Age & Sex & $\begin{array}{l}\text { Teaching } \\
\text { experience }\end{array}$ & $\begin{array}{l}\text { T/I } \\
\text { experience }\end{array}$ & $\begin{array}{l}\text { Stage of } \\
\text { programme }\end{array}$ & $\begin{array}{l}\text { Career } \\
\text { plan }\end{array}$ & $\begin{array}{l}\text { Language } \\
\text { of thesis }\end{array}$ & Thesis area \\
\hline Xianyong & Early 30s & $\mathrm{m}$ & nil & $\begin{array}{l}\text { Free lance } \\
(2 \text { years })\end{array}$ & 1st year & teacher & Chinese & $\begin{array}{l}\text { Literary } \\
\text { translation }\end{array}$ \\
\hline Shanhu & Early 30s & $\mathrm{m}$ & 3 years & nil & $\begin{array}{l}\text { 2 years after } \\
\text { graduation }\end{array}$ & teacher & Chinese & $\begin{array}{l}\text { Literary } \\
\text { translation }\end{array}$ \\
\hline Qunbo & Early 30s & $\mathrm{f}$ & 2 years & nil & 2nd year & teacher & Chinese & $\begin{array}{l}\text { Literary } \\
\text { translation }\end{array}$ \\
\hline Yanggang & Late 30s & $\mathrm{m}$ & 4 years & nil & Final year & teacher & Chinese & $\begin{array}{l}\text { Literary } \\
\text { translation }\end{array}$ \\
\hline Huifeng & Early 30s & $\mathrm{f}$ & nil & nil & 1st year & teacher & English & $\begin{array}{l}\text { Literary } \\
\text { translation }\end{array}$ \\
\hline Xinping & Early 30s & $\mathrm{m}$ & nil & nil & 2nd year & teacher & Chinese & $\begin{array}{l}\text { Literary } \\
\text { translation }\end{array}$ \\
\hline Hanbei & Late 30s & $\mathrm{f}$ & 1 year & nil & 2nd year & teacher & English & $\begin{array}{l}\text { Computer } \\
\text { translation }\end{array}$ \\
\hline Guanli & Mid 40s & $\mathrm{f}$ & 10 years & nil & 4th year & teacher & Chinese & $\begin{array}{l}\text { Literary } \\
\text { translation }\end{array}$ \\
\hline Shanlan & Late 40s & $\mathrm{f}$ & 13 years & nil & Final year & teacher & Chinese & $\begin{array}{l}\text { Translation } \\
\text { teaching }\end{array}$ \\
\hline Huaqin & Mid 40s & $\mathrm{m}$ & 4 years & $\begin{array}{l}\text { Free lance } \\
(2 \text { years })\end{array}$ & 4th year & teacher & English & $\begin{array}{l}\text { Literary } \\
\text { translation }\end{array}$ \\
\hline Pingren & Early 40s & $\mathrm{f}$ & nil & nil & 5th year & teacher & Chinese & $\begin{array}{l}\text { Interpreting } \\
\text { studies }\end{array}$ \\
\hline
\end{tabular}




\section{Findings and discussions}

Both the interview conversations and the curricular documents of all Ph.D. programmes were analyzed, following the strategy of analytic induction (Goetz and LeCompte 1984; Bogdan and Biklen 1992). The themes seemed to be centered on the following four aspects: provision of programme information, curricular issues, academic support and knowledge growth, which will be elaborated respectively in the remainder of this article.

\subsection{Programme Information}

The first theme that came out of the analysis concerned the availability of information about the doctoral programmes. On the whole, students were happy that they could find clear requirements for admission as well as those for graduation, but they also felt the need to be better informed about the aims and objectives of their programmes.

\subsubsection{Requirements for Admission}

A survey of the programme documents revealed that one aspect securing the most attention was admission requirements of the programmes. In fact, all programmes gave specific requirements for admissions. These usually included a research proposal/plan for the Ph.D. study; a master's degree or equivalent; a completed application form and an interview admission. In addition, a proof for English proficiency in the form of international English tests, such as TOEFL, IELTS is also required for those applicants without a degree obtained in an English-speaking country. For instance, in the Handbook for Research Postgradute Students of the Baptist University of Hong Kong (HKBU), the following admission requirements were given:

3. Admission Requirements

3.1 Applicants seeking admission to the Ph.D. degree programme should possess:

(a) a Master's degree from a recognized university or comparable institution; or

(b) a Bachelor's degree with First Class Honours from a recognized university or comparable institution; or

(c) any other qualification deemed by the Graduate School to be acceptable for this purpose.

3.2 Candidates under section 3.1(b) of the General Regulations should have evidence of research achievement/experience. They may be admitted to the MPhil programme initially, but with a view to proceeding to the $\mathrm{PhD}$ programme after satisfactorily passing an assessment at the time of candidature confirmation.

3.3 Candidates under section 3.1(c) of the General Regulations may be required to take a qualifying examination, in which event their progress shall be reported to the Graduate School at the end of their first year of study.

3.4 Language Requirements

Applicants may be required to prove their language abilities in English and/or Chinese by means of an interview, or, for applicants from outside Hong Kong, by means of performance in a test to show acceptable language proficiency, such as the Test of English as a Foreign Language (TOEFL), International English Language Testing System (IELTS) or the Member of Institute of Linguists (MIL) examination. 
Though HKBU did not seem to specify the exact scores for TOEFL or IELTS, other universities made them explicit. For instance, the Hong Kong Polytechnic University (PolyU) required a score of 6.0 or above in IELTS; or 550 or above in TOEFL for the paper-based test, or at least 213 in the computer-based test for an applicant to be considered for admission.

All programmes required applicants to attend interviews for admission, which were conducted either in person or over the phone for non-local applicants. There was no information about what would actually transpire at such interviews. But from the ones we attended, they usually focused on the students' general knowledge of Translation Studies, knowledge of the topic they proposed to work on for their Ph.D. research and perhaps more about their background, and at the same time, to gauge their English proficiency, particularly their spoken English. Students seemed to think favorably of the interviews.

I was so tense and nervous when I attended the interview. But I think it was a good way to find the best candidates for the programme. When there are dozens of applicants, it's hard to tell the difference and decide by merely looking at their transcripts and other documents. (Qunbo, transcripts: 3)

\subsubsection{Requirements for graduation}

Another aspect that was generally described in detail in the graduate handbooks and study schemes was the graduation requirements, which usually included: course requirements, obtainment of candidature, normative period, research thesis and oral defense of thesis.

Students were normally required to obtain their candidature within the first year and a half of their programme. Some had to go through comprehensive oral and written examinations (e.g., Chinese University of Hong Kong), whereas others might only need to submit a revised and refined research proposal to a group of examiners for approval (e.g., the Hong Kong Polytechnic University).

The normative period was usually set at three years for full-time students and six years for part-time students. Most students felt fine with it since they generally wanted to graduate sooner rather than later. However, some students, who were less prepared before starting the programme, felt tremendous pressure of the time constraint. Often they had to apply for extensions or were considering applying for extensions.

Three years is too short for me. There are so many books I'd like to read. I don't want to rush through the process and just get a Ph.D. degree. Spending a few years on an advanced degree at the doctoral level is a big investment in time and energy. I need to learn real stuff here. I'll have to ask for an extension. (Hanbei, transcripts: 6)

All students were required to complete a research thesis on a topic of their own choice. It happened that among the 11 students interviewed in this study, eight worked in the broad area of literary translation in China and cultural studies was often chosen as the explaining theory for their research. There was no specification on the length of a thesis. Students were given the choice to write their thesis either in English or Chinese. They were also required to defend their theses successfully. The language of defense was usually the same as that of the thesis.

Some universities may have additional requirements. For instance, apart from the above, the Chinese University of Hong Kong made additional requirements for 
all their graduate students: Passing the IT Proficiency Test and complete an Improving Postgraduate Learning (ILP) course "Observing Intellectual Property and Copyright Law during Research.”

\subsubsection{Scanty Information on Objectives}

As mentioned above, there were mainly two documents that gave information about the Ph.D. programmes of Translation Studies: the Graduate Handbook, which included general descriptions of the requirements for all graduate students; the Study Scheme for Ph.D. students prepared by each department, which gave more specific information about the structures of the programmes. What is most lacking is perhaps description of the objectives and aims of the programmes, as one of the interviewees observed:

One piece of very important information that is missing in the book is the aims of the curriculum. I do not know till today what's the University's aim of this programme of Translation Studies although I have my own... I really felt the need of a clear statement of the objectives when I applied for entry into the programme, because, without it, you don't know whether you will get what you want or whether your expectations will match the university's. (Guanli, transcripts: 16)

In fact, in all the curricular documents that could be found on each of the Ph.D. programmes of Translation Studies, not a single statement was found on the curricular objectives and/or aims. There might be several reasons for this omission. First the aims and objectives might generally be assumed to be known to all. Therefore, some might think there was no need to spell them out. But the reality might turn out to be quite the opposite. Without a clear statement, teachers and students know very little of the aims and objectives of these programmes. Like Guanli above, students might wonder about them when making their applications for admission. Another reason for this omission might be that these programmes were established fairly recently and thus changes and adjustments were expected along the way of its development and growth. Therefore some might consider it undesirable to have the objectives written down at this stage. Third, there were very few Ph.D. students studying simultaneously at the same programme. For example, a few years back in 2004 when some of the data for this study were collected, two of the universities had more than one Ph.D. student of Translation Studies studying at their programmes while three others had only one current Ph.D. student. Thus the departments might prefer the flexibility without a written statement of the objectives and aims, so that they could work out relevant ones according to the students they had. Today, all the programmes have more research students than before and it should be necessary and advisable to spell out the aims and objectives for teachers and students, or perhaps more importantly for prospective students.

\subsection{Curricular Issues}

The second major theme of findings related to such curricular issues as course provision, research methodology, language of dissertation and selection of research topics. 


\subsubsection{Courses for Ph.D. Students}

Some programmes required students to take courses and students generally felt that requiring them to take courses during the programme were good for them. But they hoped the department could offer courses specially designed for Ph.D. or M.Phil. students rather than require them to take courses from Part-time MA Taught Programmes or even undergraduate translation courses, which, in many cases, do not address their specific needs as research students.

I would love to take some courses during the programmes where teachers and students can learn and exchange ideas together. It's more stimulating than reading alone in your office or dorm. But I didn't like the idea of taking courses specially designed for parttime MA students. They have different goals and expectations... It's sometimes a total waste of time for me. (Huaqin, transcripts: 12)

\subsubsection{Research Methodology for Ph.D. Students}

The students felt that they really needed a course on translation research methods. Such a course should help them understand all the methods available to them for their research. For now, they were using the method that their supervisors often used in their own research, oblivious to other methods that might be available to them. They saw research methods as a most important tool for their future research. As one of them said,

[t]hough I may not use all the methods for my dissertation, I would like to know the options I have. Besides, I will very likely need to use them later on in my academic career. At least I should be able to teach them to my future M.Phil. or Ph.D. students. (Qunbo, transcripts: 17)

For now, none of the Ph.D. programmes in Hong Kong tertiary institutions offers a course on translation research methodology or any systematic discussions on this topic. The Chinese University of Hong Kong runs a two session seminar for all research students of the university. But it was a very preliminary introduction to the general quantitative and qualitative research methods used in social studies. Students generally found they were of little true use to them. They craved for a course specially designed for Translation Studies.

If I have to take one course, it has to be research methods on how to do proper research in translation studies... If you ask me to give a brief account of the research methods of translation studies today, honestly, I don't know much else except what I'm doing for my thesis. (Shanlan, transcripts: 17)

On a more positive note, the research programmes in several universities in neighboring Taiwan seem to have laid stress on teaching research methods to their students. Take National Taiwan Normal University for instance. Research methodology was stipulated as one of the five key components of the Ph.D. curriculum, namely Required Course for All Students (the dissertation), Core Courses, Research Methodology Courses, Theoretical Courses and Electives. Five courses are listed under Research Methodology (namely Topics on Research Methods for Translation Studies, Topics on Research Methods for Interpretation Studies, Qualitative Research Methods, Quantitative Research Methods and Survey Research Methods) and two more under Electives (Research Methods in Translation Studies and Research 
Methods in Interpretation Studies). The course titles suggest that both quantitative and qualitative research methods are on offer and so are research methods for written translation and oral interpretation. However, it is also obvious that the training is on conducting data-based empirical research, while little is provided on non-data based research in Translation Studies (Li 2005b).

\subsubsection{Selection of Thesis Topics}

For all doctoral students, dissertation is usually the most important part of the programme. Therefore they usually spend much time deciding on the topic of their dissertation. Eight out of the 11 students interviewed worked in the area of literary translation from mostly a historical-cultural perspective. While it is not advisable to draw any conclusions based on 11 students' choice of research topics for their theses, the focus on literary translation and descriptive Translation Studies seemed obvious. Translation of other genres was seldom chosen as a topic for research. For instance, technical and business translation accounts for by far the biggest proportion of translation work in the world today. In sheer volume and financial worth, technical and business translation far exceeds the translation of literary texts (Kingscott 1995; Venuti 1995). However, they received much less attention in $\mathrm{Ph} . \mathrm{D}$. research than literary translation. The same was true of interpretation studies. After China's accession to the WTO, the demand for interpreters, particularly simultaneous interpreters, has risen sharply and it has been growing at a fast speed. To the envy of millions of people, simultaneous conference interpreters are now called "gold collars" in China and they make between $¥ 6,500$ and $¥ 8,000$ (approximately $\$ 800$ to $\$ 1,000$ ) for half a day in Shanghai, or an hourly rate of $¥ 2,000$ (approximately \$250), topping the China Salary Guide. ${ }^{4}$ However, there has been little research interest in interpreting studies among the Ph.D. students in this study.

Just like translation programmes at the undergraduate level, Ph.D. programmes of Translation Studies should not be entirely independent of the social and market needs (Li 2000). There are so many universities and each has its own different traditions of teaching and research. To meet the needs of different programmes, we need translation teachers of different research interests and experts of different specializations. Besides, working on similar topics and from similar perspectives can be counterproductive, as one interviewee observed,

I don't appreciate much that everybody seems to be working on more or less the same sort of topic - just pick a well-known literary translator-writer in recent Chinese history, dig into their life stories, read their translations and writings, examine the social and political situations of their times and then try to relate their translations to their life and the socio-political situations, focus on such issues as ideology, patronage, poetics etc... This would have been good but now everybody is doing this. It's unusual. It's like everyone is using the same model. (Qunbo, transcripts: 26)

Thus, this issue of concentration on a few hot topics while neglecting most others among graduate students needs to be addressed. Towards that end, some sort of advance planning on the part of the administration should be sufficient. For instance, the translation programmes may devise five-year plans about the specializations for prospective students and refer to them while admitting new students. That way, we can ensure a wider range of research topics among our doctoral students and very likely a better match of students' interests with teachers' expertise. 


\subsubsection{Language of Dissertation}

In almost all the doctoral programmes of Translation Studies, students are given the choice to write their dissertation either in English or Chinese, their mother tongue. Among the 11 students, all but three wrote or would write their theses in Chinese and four of them vehemently defended their choice of writing in Chinese. They mainly presented two arguments. First, since Chinese was their mother tongue, they would be able to write faster and express themselves much better in the language than in English. They argued that since many of them worked on literary translation in China, much literature on related research was written in Chinese. As such, to write their thesis in Chinese rather than in English would save them the hassle of translating Chinese citations into English and hence speed up their writing.

Three years aren't that much time. I have to take courses, write research proposals, pass candidacy, write thesis, and so on. If I write my thesis in Chinese, I don't need to translate the citations into English and that can save me a lot of time. (Yanggang, transcripts: 26)

However, those who prefer writing their dissertations in English thought that giving students the option to write their theses in Chinese was not desirable. They contended that students' lack of confidence in writing their dissertation in English only meant it was important and necessary for them to practise more writing in English. To me, translation students should be required to write their dissertations in English. Even if some of them may not be able to write directly in English, as doctoral students in Translation Studies, they should at least be able to translate their own theses into good English. If they cannot even produce a decent translation of their own theses, they do not deserve the degrees they are getting. Can we imagine a translation teacher who cannot even translate his or her own doctoral thesis?

In fact, in almost all the universities, apart from programmes of Chinese studies, translation is perhaps the only programme that allows their Ph.D. students to write their theses in Chinese. This is rather ironical given the fact that translation students are supposed to have much better English skills than almost all other programmes (engineering, philosophy, medicine etc.). Furthermore, they have often claimed that one of the major reasons they became interested in translation is because translation can break down the barriers of communication between different peoples and cultures. And yet, by writing their Ph.D. theses in Chinese, a language inaccessible to most of the world, they have in effect created barriers rather than facilitated communication among different cultures. Given the fact that Translation Studies is a relatively young discipline and only a small number of $\mathrm{Ph} . \mathrm{D}$. theses in Translation Studies are produced each year, every doctoral thesis contributes an invaluable piece of literature for the discipline. It is therefore regrettable that these important theses are sometimes inaccessible to many people from other parts of the world due to the language barrier.

Some students also argued that writing their theses in Chinese would make it easier for them to find a publisher in China. Since they usually hoped to find a Chinese publisher to publish their theses, they thought that writing their theses in Chinese would save them the trouble of rending them into Chinese.

I know a Chinese publisher in Beijing and I'm going to talk to them for the publication of my thesis. So I've decided to write it in Chinese. (Guanli, transcripts: 17) 
It is true that Chinese publishers seldom publish English books of their own, although several major publishers have been reprinting English academic books provided by overseas publishers for distribution in China at a fractional price of the original (e.g., Shanghai Educational Press and Foreign Language Teaching and Learning Press). Therefore, in most cases, the students would need to translate their thesis into Chinese for publication had they written theirs in English. However, this may not necessarily be true because there are so many more English publishers to publish their theses in English in the world, and when that happens, their research will reach out to a much larger audience than publishing them in Chinese only.

However, it should be noted that this is not a problem unique to Hong Kong. In fact, many Translation Studies programmes in other parts of the world have made similar decisions regarding the language for writing theses. We, as well as our colleagues, have so often come across translation theses written in Arabic, Finnish and Russian, the students' native language, and felt the frustration of not being able to access the valuable literature. It is perhaps high time for all Translation Studies programmes to reconsider this requirement.

\subsection{Academic Support}

Another theme that came up in the analysis was the academic guidance and support system the students received at their programmes. The form of supervision varied from institution to institution. Some preferred sole supervision while others opted for joint supervision where there was a lead and a co-supervisor. The students reported they were generally happy with the supervision they received. Some had an extremely positive experience and considered the supervision they received timely and constructive.

I guess I'm a lucky person. I have had the best supervisors one could ever have. They were both friends and teachers to me. I learned so much from them... He [one of the two supervisors - note by the present researcher] was always available to me almost any time. I could pick up the phone and call him any time. (Mingjian, transcripts: 9)

Several of the interviewees also reported making use of the Internet to consult experts worldwide on issues of interest to them and received useful information and guidance. They really benefited from this expansion of supervision and research community via the Internet.

I've kept in touch with Prof. XXX [name omitted - note by the present researcher] since I got to know him two years ago by sending him emailed messages. Besides sending me updated information about translation events and conferences, she's given me very helpful comments on my papers and some of the chapters of my dissertation. (Pingren, transcripts: 23)

The students all recognized the importance of exchanging ideas and information with fellow students. They believed that professional conversations and dialogues could sharpen their thinking about their questions and research issues. However, it was difficult for them to avail themselves of such exchanges of information within the same department and even the same university since there were usually no more than a couple of research students or, at times, even only one student in each one of these programmes of Translation Studies. Sometimes they could feel very lonely 
academically. They therefore expressed the desire to build a community of research students across universities.

For now, I'm the only student of Translation Studies in the Department. You don't even have anyone to talk to when you have a question in your reading. I've heard that there are students of Translation Studies in other universities here. I'll have to get in touch with them. (Huifeng, transcripts: 11)

The students were all eager to attend research seminars and conferences on Translation Studies or related areas. They all spoke highly of a regular seminar series at Hong Kong Baptist University, where renowned translation scholars and graduate students were invited to give talks on topics they had been working on. They believed the discussions following each talk were inspiring and thought-provoking. Besides, it was also a good way to meet people with similar research interests.

They also took interest in attending international conferences to present their findings and reported that this was also a good learning experience for them and another venue to meet with colleagues with similar research interests. To the envy of many graduate students in other parts of the world, Ph.D. students could usually obtain funding from their universities to cover in full or part of their conference expenses.

\subsection{Knowledge Growth}

The final major theme of the findings is on knowledge growth of the doctoral students during their doctoral programmes. This will be discussed as against the model of knowledge structure for translation teachers discussed earlier.

\subsubsection{Research Abilities (Research Knowledge)}

All the Ph.D. programmes were obviously and rightfully research-oriented. This was evident in both the students' expectations and their learning activities as well as in the programme requirements.

First, in the admission requirements, the importance of a research proposal was highlighted. While studying at the programmes, students mainly had to do three things: take courses, obtain candidature, write and successfully defend a research thesis. Some programmes stated clearly that the programme is by research only (e.g., Hong Kong Baptist University). The requirements point mainly towards the training of the students' research abilities.

Such a focus was perhaps even more obvious in the students' expectations and their learning activities. When asked why they wanted to pursue a Ph.D. degree in Translation Studies, they all reported that among others, access to books on Translation Studies recently published overseas would help them with their research, since many of them were from the Chinese mainland where such access was still rather difficult though fast improving in recent years.

One of the biggest advantages of pursuing a doctorate here in Hong Kong is the amount of expertise and books on Translation Studies that was not available to me on the Chinese mainland. At my home university, I could not find a single book on translation studies that was published overseas in English. Here, basically you can find almost all the titles you want. (Xinping, transcripts: 6) 
According to the interviewed students, while studying at the programme, apart from fulfilling their duties of teaching assistants, usually in the form of leading tutorials or grading translation assignments, they spent all their time on research finding a research topic, refining research proposals, and most importantly, writing their thesis. Almost all considered the time they spent on teaching represented undesirable interruptions of their research and preferred no teaching duties at all if they had a choice.

Besides, in the interviews they freely admitted that they focused almost exclusively on the development of their research interests and abilities during the programme.

My focus is to write a good thesis to be published after it's completed. What's most important for a university teacher today is to publish. I need to make use of the few years here to learn to write good research papers and master good research methods for doing translation research. (Yanggang, transcripts: 23)

Since all of the students indicated they would become university translation teachers, research would certainly be expected of them and fine research abilities would be essential and vital to their career as university teachers. Therefore such a focus on development of students' research abilities was absolutely warranted. However, if the focus on the development of students' research abilities was maintained at the sacrifice of development of their other necessary and important knowledge (e.g., teaching) and skills (translating), we should certainly be seriously concerned.

\subsubsection{Pedagogy (Knowledge of Teaching)}

As discussed earlier, a university translation teacher is first of all a teacher and thus should possess a good knowledge of teaching in addition to the research knowledge expected of them. However, it seemed that development of students' pedagogical abilities was largely kept out of the curriculums of Ph.D. programmes in Translation Studies. A review of all the requirements for Ph.D. programmes showed only two aspects associated with teaching, that is, the courses required of students and assignments of teaching assistants. The teaching assignments could be effective for the development of students' teaching abilities and application of their research. But unfortunately they generally considered such teaching duties as an unwelcome burden hampering their research. With such an attitude, they would not get the most out of their teaching, hence little growth in their pedagogical knowledge.

Of course, I would very much like to be exempted from the teaching duties if I have a choice. Teaching tutorials takes too much of my time. I need to do preparations before class and grade students assignments. It would be nice if I could just work on my research proposal for now. (Xianyong, transcripts: 16)

Taking courses could be helpful for the students' future teaching apart from their research. The courses, if well designed, could help them in many ways. As far as developing their teaching competence is concerned, the courses would certainly increase their subject matter knowledge, which would definitely help with the development of their overall knowledge of teaching. But it was unfortunate that not all programmes required students to take courses. Some programmes that did require coursework did not offer many courses specially designed for Ph.D. students except 
individual studies students took from their supervisors or other individual teachers. This might affect the students' acquisition of the content knowledge required for their future teaching. Of course, their own reading of Translation Studies could facilitate to some extent development of their content knowledge. However, this renders little help to their growth of other knowledge including general pedagogical knowledge, pedagogical content knowledge and support knowledge.

To make matters worse, none of the interviewed students showed any interest in or felt any need for developing their knowledge of teaching despite their desire and plan to become teachers.

I haven't done any teaching but I've taken so many courses. I don't need to learn or practice how to teach. I can just do what my teachers do and teach what my teachers have taught me. That should be fine. (Xinping, transcripts: 16)

While some claimed they had former teaching experience to rely on, others might not have any teaching experience at all. Besides, it should also be noted that the students with previous teaching experience did not actually teach translation but rather ESL and/or literature courses. Thus they might have some general pedagogical knowledge, but their pedagogic content knowledge or support knowledge, which is more relevant for teaching translation in tertiary institutions, was very limited.

I taught many courses, such as College English, English composition, spoken English... (Xianyong, transcripts: 16)

I started teaching in 1989. I did the teaching while doing my master's... I only taught one year of translation and the rest all literature and linguistics. (Shanhu, transcripts: 16)

To sum up, although some students might have increased their content knowledge by taking appropriate courses or through their own reading and have strengthened their overall knowledge of teaching if they could draw upon teaching assistantships during the programme, the curriculums, programme requirements and students' attitudes all showed that development of their knowledge of teaching was not given due attention in the curriculums. In fact, none of the programme requirements mentioned the development of students' knowledge of teaching and none of the students indicated that this was part of their goals of the Ph.D. programme. Thus it can be fairly safe to say that development of students' knowledge of teaching was largely omitted from the programmes.

One may be quick to point out that perhaps no other disciplines except education require this training for their Ph.D. students. However, we cannot justify our choices simply because we are not alone in this. In fact, more attention has been given to training university teachers of different disciplines in recent years. For instance, several conferences have recently been held to channel international resources and efforts towards research on this topic (Gibbs 1996; 1997; 1998; Gibbs and Coffey 2004). We therefore believe that the development of students' teaching abilities should be included in the training of our research students. But this first of all requires a change of perceptions both among the administration and students of the programmes. The relevance and importance of such a component in the curriculum must be seen before any true change can take place. But how to incorporate the teaching pedagogy into the curriculum is certainly something that merits further research. 


\subsubsection{Translating (Knowledge of the Trade)}

All the students wanted to teach translation at universities. They all wanted to become teachers, and all teachers of translation at universities. As discussed earlier, a teacher of translation needs to have knowledge/ability of translating in addition to knowledge of research and teaching. However, none of the translation programmes asked for translation experience in the admission requirements or examined the applicants' translation abilities in considering their applications. And none of the programmes required students to further train and/or improve their translation abilities during their programmes. Therefore, on the whole, the programmes largely overlooked the component of translating knowledge/ability that should have been included in the curriculums. For years, these programmes seemed to have been producing another kind of people who would need to go through one of the crash courses of translation teacher training as discussed by Gabr (2001) before they could start teaching. Such crash courses were for professional translators who will teach; teachers who need to know the market and improve their translation skills (Gabr 2001), and now additionally researchers who need to improve both their teaching knowledge and their translation abilities.

Once again, a change of perceptions in both the administration and students is needed before any curricular changes can be devised and implemented. And how to incorporate this component of translating knowledge into the curriculum needs further exploration and falls beyond the scope of this paper.

\section{Summary and conclusion}

To sum up, the doctoral programmes in Hong Kong provided plenty of information on entry and graduation requirements, which provided useful guidance to students in their application for admissions and their later study at the programmes. However, the missing important information on the overall aims and objectives of the programmes might have caused difficulty in some students' decisions to apply for admissions.

Students were generally happy with the supervision they received. They very wisely took initiatives in reaching out to other experts of Translation Studies in other parts of the world via the Internet and benefited tremendously from the consultations they sought from them. Students were aware of the importance of academic networking and actively participated in translation seminars and international conferences.

Students in general preferred taking courses specially designed for doctoral students where they could exchange thoughts and stimulate thinking among them. One course considered highly desirable was research methods for Translation Studies, which unfortunately was not offered in any of the doctoral programmes of translation studies in Hong Kong. Two other major issues that came out of the study were concerned with the selection of research topics for doctoral students and the language of writing for their thesis. At present, the overwhelming penchant for research on literary translation from historical-cultural perspectives seemed obvious. Relatively little research interest was found on non-literary translation and other research methods, e.g., the linguistic approach. Such lack of variety is detrimental to Translation Studies in Hong Kong. 
The views on the language of writing their theses seemed to diverge. Given the fact that many students did not have confidence in writing in English, this actually made it all the more important and necessary for them to write in English simply because they needed the practice. Also, they should be better off in the long run if and when they became versed in English academic writing.

All the research programmes in Translation Studies seemed to have duly emphasized the development of students' knowledge of research, which corresponded very well with the students' expectations - to improve and strengthen their research skills and abilities. All the interviewed students reported having "learned a lot" and "seen a radical change in their perceptions of how translation research should be carried out" (Huaqin, transcripts: 21) after studying at the programmes for some time.

In regard to their knowledge of teaching, students reported having improved their content knowledge by attending courses and reading Translation Studies literature during their programmes. However, three other aspects of the knowledge of teaching, namely the pedagogic knowledge, the pedagogic content knowledge and the support knowledge were excluded entirely from the programme curriculums, which is perhaps most detrimental to the teacher education function of these programmes.

Similarly, the knowledge of the trade as the third major component of translation teacher knowledge was also kept out of the curriculums. Neither the institutions nor the students themselves saw the need to enhance their practical translating abilities. Apparently, the current setup of Ph.D. programmes is to train researchers of Translation Studies, rather than translation teachers with fine research abilities.

Such results suggest an obvious positivistic thinking among some teachers and administrators in translation programme development and teacher education. Many teachers seem to believe that good subject matter knowledge will necessarily make someone a good teacher and the most important role of a teacher is to transmit knowledge accumulated in their mind to students, the empty receptacles ready to be filled. Unfortunately, such a traditional teacher-centred classroom alone cannot effectively teach our students the wide range of professional and interpersonal skills, knowledge and competencies they require to meet the challenges and opportunities presented by the fast changing language services market (Kiraly 2000). What really matters for them today is to develop problem-solving abilities and the ability to handle translation tasks with appropriate strategies and ample confidence (Brown 1998; Li 2000; Wakabayashi 2002). It is therefore imperative to make the development of such abilities the focus of the translation programmes. Such a curriculum innovation will then have to begin with fundamental shifts in the values and beliefs of all participants (Brindley and Hood 1990; Burns 1996). Teachers, students, administrators and all other stakeholders will have to reconsider what a "good" translation teacher and researcher should be and what constitutes good training and education for research degree students. Only with these changes can we be sure that quality translation teachers with fine research skills will be trained in the research programmes of Translation Studies. 


\section{NOTES}

* This article is based on an earlier presentation at Monterey Institute of International Studies in 2005.

1. MTI is the official title of the new MA taught programmes in translation and interpreting launched by the Chinese government a few years ago.

2. Hardly any research could be found on the training of doctoral students in Translation Studies when this project started in 2004 and its initial findings were reported at Monterey Institute of International Studies in 2005. However, when the present article was under review in late 2008 and early 2009, some research attention was finally given to this issue in Europe, e.g., a special issue on training doctoral students in Translation Studies in The Interpreter and Translator Trainer $(3 / 1,2009)$ and a conference on this topic at University of Vienna in December 2008.

3. M.Phil. students here refer to those studying in a research-oriented master's programme, as opposed to MA students in a course-based or taught master programme in Hong Kong. The former may be called MA students in other countries as is the case in the Chinese mainland.

4. The numbers were from Hong Kong Metro Daily, June 2004.

\section{REFERENCES}

BALl, Deborah (1988): Unlearning to teach mathematics. For the Learning of Mathematics. 8(1):40-48.

Bogdan, Robert and Biklen, Sari Knopp (1992): Qualitative Research for Education: An Introduction to Theory and Method. Boston: Allyn and Bacon.

Brindley, Geoff and Hood, Sue (1990): Curriculum innovation in adult ESL. In: Geoff BRINDLEY, ed. The Second Language Curriculum in Action. Sydney: Macquarie University, 232-248.

Brown, Allison (1998): Developing resources for flexible delivery. Teaching \& Education News. $8(2): 1-3$.

Burns, Anne (1996): Collaborative research and curriculum change in the Australian Migrant English Programme. TESOL Quarterly. 30(3):591-598.

CARter, Kathy and Doyle, Walter (1987): Teachers' knowledge structures and comprehension processes. In: James CALderheAD, ed. Exploring Teacher Thinking. London: Cassell.

Chan, Kar Yan (2008): MA Translation Programmes in the United Kingdom: A Curricular Investigation. MA dissertation, unpublished, School of Oriental and African Studies, University of London.

Connelly, F. Michael and Clandinin, D. Jean (1985): Personal practical knowledge and the modes of knowing: Relevance for teaching and learning. In: Elliot W. EIsNER, ed. Learning and teaching the ways of knowing (National Society for the Study of Education Yearbook). Chicago: University of Chicago Press.

DAY, Richard (1993): Models and the knowledge base of second language teacher education. University of Hawai' $i$ Working Papers in ESL, 11(2), 1-13.

Day, Richard and ConkLIn, Hilary (1992): The knowledge base in ESL/EFL teacher education. Paper presented at the 1992 TESOL Conference, Vancouver, Canada.

Elbaz, Freema (1983): Teacher Thinking: A Study of Practical Knowledge. London: Croom Helm.

GABR, Moustafa (2001): Trial and Error or Experimentation or Both. Journal of Translation. 5(4):1-13.

GABR, Moustafa (2004): Toward Re-Professionalization of Translation Teaching. Paper presented at the $1^{\text {st }}$ Conference of the International Association for Translation and Intercultural Studies: Translation and the Construction of Identity (Seoul, 12-14 August 2004). Sookmyung Women's University.

GibBs, Graham (1996): Preparing university teachers: an international overview of practice and issues. (International Conference on Improving University Teaching, Nottingham, July 1996).

Giвbs, Graham (1997): Preparing university teachers world-wide: issues and practices. Das Hochschulwesen. 45(1):18-21. 
Giввs, Graham (1998): The preparation of university teachers in Europe and Australasia. In: James ForRest, ed. University Teaching: International Perspectives. Boston: Brock.

GibBs, Graham and Coffey, Martin (2004): The impact of training university teachers on their teaching skills, their approach to teaching and the approach to learning of their students. Active Learning in Higher Education. 5(1):87-100.

Goetz, Judith Preissle and LeCompte, Margaret Diane (1984): Ethnography and Qualitative Design in Educational Research. Orlando: Academic Press.

Johnston, Bill and Irujo, Suzanne (2001): Research and practice in language teacher education: voices from the field; Selected papers from the first international conference on language teacher education. CARLA Working Paper Series. Vol. 19. May 2001: 297 p.

Kiraly, Don (2000): A Social Constructivist Approach to Translator Education: Empowerment from Theory to Practice. Manchester/Northampton: St. Jerome Publishing.

Kingscott, Geoffrey (1995): The impact of technology and the implications for teaching. In: Cay Dollerup and Vibeke Appel, eds. Teaching Translation and Interpreting. Vol. 3. Amsterdam: John Benjamins Publishing Company, 295-300.

Leinhardt, Gaea and Smith, Donald A. (1985): Expertise in mathematics instruction: subject matter knowledge. Journal of Educational Psychology. 77(3):247-271.

LI, Defeng (2000): Tailoring translation programmes to social needs: a survey of professional translators. Target. 12(1):127-149.

LI, Defeng (2005a): Training translation/interpreting teachers and researchers: an exploratory study of translation programs in Hong Kong. (Professional education of 21st century translators and interpreters, Monterey, California, Monterey Institute of International Studies, 8-11 September 2005).

LI, Defeng (2005b): Research methodology in translation studies: TAP as a case of example. Translation seminar. Guangzhou University of Foreign Studies, October 2005.

Рyм, Anthony (200): Innovation in translator and interpreter training. Across Languages and Cultures. 1(2):209-273.

Rosas, Marta (2004): Review of Don Kiraly's a social constructivist approach to translator education. Translation Journal. 8(4). Visited on 28 June 2011, <http://translationjournal. net/journal//30review.htm>.

Shulman, Lee S. (1986a): Those who understand: A conception of teacher knowledge. American Educator. 10(1):43-44.

Shulman, Lee S. (1986b): Those who understand: Knowledge growth in teaching. Educational Researcher. 15(2):4-14.

Shulman, Lee S. (1987): Knowledge and teaching: Foundations of the new reform. Harvard Educational Review. 57(1):1-22.

Venuti, Lawrence (1995): The Translator's Invisibility: A History of Translation. London: Routledge.

WAKABAYASHI, Judy (2002): Induction into the translation profession: Through internet mailing lists for translators. In: Eva Hung, ed. Teaching Translation and Interpreting. Vol. 4. Amsterdam: John Benjamins, 47-64. 